\title{
Profanity in songs. Seeking the limits of freedom of speech, and the reproduction and sanctioning of contemporary linguistic tendencies
}

Colloquial language, as the basic tool of social communication, seems particularly sensitive to various transformations in community life. Its specificity is its naturally democratic nature as it is subjected to various pressures from the surroundings (the language of the media, widely considered culture, education, and the family), it is a source of change in the official language participating in the constant game of socio-linguistic influences. One problem in seeking the limits of freedom of speech is the propagation of vulgarisms, which in the Polish language of the last few decades have occupied an excessively high position. Linguists consider a specific historical period as one of the breakthrough moments:

The years 1980-1981 saw the development of a new language, which was widely used by the youth. The language was saturated with profanity. The language, or rather the youth slang, reflected the civilisational and moral transformations which occurred in Poland in the late-1970s and throughout the following decade. That language, perceived and understood as a mirror of the youth's subconscious, was dramatically different from the common language of Poles. That vocabulary led its life in the so-called third circulation, ousted to the fringes or outside any official kind of Polish language, though it reflected many unrests, not only that of the youth. (...) The development of brutalisms and profanity were, to some extent, influenced by the increased brutality of the community and moral life in Poland (foul, vulgar language), and there also reappeared terms known from Newspeak (plurality, subjectivity, etc.) The increased brutality of everyday morality resulted in the youth increasingly often using so-called dynamites, i.e. words beginning with $k, p, c h .{ }^{1}$

* PhD, e-mail: krzysztof.gajda@amu.edu.pl, Research Institute of Literature and Independent Culture, Faculty of Polish and Classical Philology at Adam Mickiewicz University in Poznan, 61-701 Poznan,10 Fredry street.

${ }^{1}$ M. Jędrzejewski, Młodzież a subkultury, Wydawnictwo Akademickie “Żak”, Warsaw 1999, p. 227. [English version translated from Polish]. 
One could probably seek various socio-political events which influenced the "increased brutality of the community and moral life in Poland." However, I would like to focus on another aspect: the mutual relationship between colloquial language and the lexical layer of songs as an area of popular egalitarian culture, i.e. participating in that struggle of linguistic influence.

\section{Literary and humorous songs}

In a study Słowo w piosence. Poetyka współczesnej piosenki estradowej, Anna Barańczak indicated one of the features of the lexical layer of the commercial Polish songs of the 1960s and 70s, i.e. from before the historical moment specified above:

And finally, there is one more limitation, this one of a stylistic-sentimental nature (...) It consists of eliminating from a text lexical units originating from "low" style levels: any vulgar, jargon or pungent expressions, or even only marked with excessive "anti-aesthetic" expressiveness (of course the tendency does not apply to humorous songs, as well as literary songs or songs styled to resemble folk songs). ${ }^{2}$

Based on the above statement, first of all: popular songs (commercial, stage performed) at least from the beginning of the 1980s corresponded with Orwell's vision of the world where language offered limited opportunities for expressing negative feelings; secondly, paradoxically, it was the version of culture considered higher, the literary culture, as well as the more artistically sublime genre of songs, which sanctioned profanity as a means of expression, using it more boldly than the commercial genres. Linguistics have, in fact, emphasised the significance of literature for the expressiveness of everyday language. ${ }^{3}$ Should one recall the most pungent examples offered by Andrzej Bursa or Rafał Wojaczek, one notices how far literature exceeded in that area the appropriate and tempered poetics of stage song. Literary proof of linguistic brutality can also be found in poetry after 13 December 1981. When discussing the language of martial law

${ }^{2}$ A. Barańczak, Stowo w piosence, Zakład Narodowy im. Ossolińskich, Wroclaw 1983, p. 78. [English version translated from Polish].

${ }^{3}$ Władysław Lubaś posited even at the end of the $20^{\text {th }} \mathrm{c}$. that the literary tradition was the main reason for increased use of the common version of the Polish language in public communication. Referring to Dąbrowska, Białoszewska, Różewicz, and Myśliwski he argued that they influenced the normative sanctioning of colloquial language in some genres of public communication. Vide W. Lubaś, "Rola słownictwa potocznego w polszczyźnie ostatniego dziesięciolecia”, in: Stownictwo współczesnej polszczyzny w okresie przemian, J. Mazur (ed.), Wydawnictwo Uniwersytetu Marii Curie-Skłodowskiej, Lublin 2000, pp. 59-68. 
poetry, in a chapter entitled "Tolerowanie wulgaryzmów" (Tolerating profanity), Dobrochna Dabert offered the following diagnosis:

A more drastic form of isolating oneself from Newspeak was the use of profanity. That constituted a challenge to the sanctimonious language of the authorities. The use of words with a high expressive load aided the release of accumulated negative emotions directed against the authorities and the system. Obscenities did not appear only in anonymous street poetry; high poetry did not avoid them, though it used them much more rarely and only as intentional expressive means. ${ }^{4}$

Evidently, profanity is sometimes considered as a manifestation of the objection to existing reality, and a form of community rebellion by disrupting applicable norms, and breaking linguistic taboos. It served a similar function in some songs in the early-1980s, being justified precisely by the historic situation, as an element of linguistic separation from the artificial official character. Andrzej Garczarek was a representative of the literary song. His lyrical ballads about various facets of life could not avoid roughness of language or descriptions of the dark sides of reality. His literary-linguistic manner did not require him, though, to use expressions considered vulgar. And yet he was the author of a song which became a hit in the 1980s; not in the media sense, but rather in terms of its folk message as an output propagated within the community: in dorm rooms, student club rooms, and during singing at hikers' shelters or bonfires. I am referring to the song Przyjaciót nikt nie będzie mi wybierat, which, while carrying non-conformist content, utilised a violently expressed statement:

przyjaciół nikt nie będzie mi wybierał wrogów poszukam sobie sam. dlaczego kurwa mać bez przerwy poucza ktoś w co wierzyć mam...? no one will choose my friends I'll find my own enemies. why, the fuck, all the time does someone tell me what to believe in...? ${ }^{5}$

The song was written in 1981, i.e. during the Carnival of Solidarity. It was a time when a limiting of the influence of censorship enabled a more unconstrained expression of one's emotions and feelings towards the officially created reality. The biggest meeting of disobedient song artists was held during Przegląd Piosenki Prawdziwej (True Song Festival) at the Gdansk Olivia Arena in August 1981. Andrzej Garczarek was warmly received, while Jacek Zwoźniak received

${ }^{4}$ D. Dabert, Zbuntowane wiersze. O języku stanu wojennego, Wydawnictwo WiS, Poznan 1998, p. 108. [English version translated from Polish].

${ }^{5}$ A. Garczarek, Grafiki, Biblioteka bardów (series), Twój Styl, Warsaw 1999, p. 56. [English version translated from Polish]. 
ovations for Piosenka na wszelki wypadek, where the following fragment was received particularly enthusiastically:

I nie trzeba obstawiać się wojskiem,

Bo bez sensu dziś taka robota,

Lecz w tę dupę wypiętą na Polskę

Kopa dać, choćby była czerwona!
And you don't need to surround yourself with soldiers,

Because it's pointless today,

But that arse which doesn't give a shit

about Poland

Kick it, even if it's red! ${ }^{6}$

The author received the main prize: the Golden Gag at the festival; it was the peak of the Carnival of Solidarity.

One author who never had any problems with censorship, as he never submitted his lyrics for approval, was Jan Krzysztof Kelus. The language of his songs was, already in the 1970s, much different from the principles of stage song, considering his completely different communication situation. Regardless of the potential opportunities an author who explored the far reaches of colloquial speech, free from the limitations of censorship had, even his lyrics were not saturated with profanity. However, there was one rather symptomatic case: In Przed nami byto wielu (czyli Cohen po polsku), there is a confession amplified with intertextuality:

A może będziesz wolał gdy wrócisz już z powrotem śpiewać o nieznajomej spotkanej w „Chelsea Hotel” „o wszystkich co przed nami na chwilę przed rozłąką kochali się w hotelach kochali się na łąkach..." ... a potem ktoś odchodził choć przedtem się kochali a ciebie, kurwa, zawsze zwyczajnie zabierali
Or maybe you will rather when you come back again sing to a stranger met at the Chelsea Hotel "about all who before us a moment before parting made love in hotels made love in meadows..." $\ldots$ and then someone leaves though they made love before and you, fuck me, they took away like that

The entire text was a dispute founded on authenticity with the translations of Leonard Cohen's songs by Maciej Zembaty, the biggest promoter, and the most popular translator and performed of the Polish versions. The idyllic

${ }^{6}$ Lyrics based on an audio recording Zakazane piosenki. I Przegląd Piosenki Prawdziwej 20-22.08.1981. [English version translated from Polish]. Interestingly enough, in its internet version, the lyrics have a repeated final line in the form: Kick it, even if it's gold!; vide http://www. tekstowo.pl/piosenka,jacek_zwo_niak,na_wszelki_wypadek.html (accessed on: 13.12.2017). 
description from the first part of the quoted fragment, with the inserted quotation from Zembaty's version, was confronted with the description of political oppression due to which art and the language of creative output could not be free from the most basic emotions in the face of injustice. The song in its printed version received a telling note: Białołęka, July 1982, i.e. it was an artistic testimony to the situation of being interned, and the related emotions. An emphatic signal of the distorted community relations was the curse included in the penultimate line, which shattered the artificiality of the pathos of previous fragments of the lyrics.

The final case in the area of artistic song applies to Jacek Kaczmarski. The author of over 650 songs, he virtually never used profanity in his official works; his model of song writing and performing required him to avoid low levels of the language. The individual cases resulted from quoting other people's statements, and do not deserve any further consideration. It is noteworthy that throughout a significant part of his career, Kaczmarski remained outside the influence of the PRL's (People's Republic of Poland's) censorship, and surely there were no institutional limitations that would had prevented him from exploring thus understood linguistic freedom. There was, however, an example of the Bard's intentional violation of norms on an unofficial tape cassette recorded during a private concert, which was later published, with the artist's consent, in the form of a second (or maybe even third) circulation cassette tape. The title song Pijany poeta from the cassette tape did not introduce any obscene content. However, the joke told by Kaczmarski after the song, did indeed:

Czy mogę Państwu zadać zagadkę? Ależ oczywiście, prosimy. Dlaczego w piździe nie ma krzeseł? Jest pełna konsternacji cisza... Jak to dlaczego? Żeby chuj stał. I jeżeli towarzystwo się śmieje, to znaczy, że można się bawić dalej. Jeśli towarzystwo się nie śmieje, to należy się spakować i wyjść. Więc piosenka Pijany poeta działa na tej samej zasadzie.
Can I offer you a riddle? Yes, of course. Why are there no chairs in a cunt? Silence full of confusion... Isn't it obvious? So the prick has to stand. And if the gathering is laughing, that means the party can continue. If the gathering is not laughing, it's time to pack up and exit. So the song Pijany poeta works the same way. ${ }^{?}$

Kaczmarski, perceived in the 1980s as the nation's consciousness, the Bard of Solidarity, thus tried to crack the plinth on which his countrymen had already placed him.

${ }^{7}$ Text based on a tape cassette: J. Kaczmarski, Pijany poeta, Kaston 052. [English version translated from Polish]. 
Those were, however, all cases from artistic areas which could be defined as literary or comedy song, i.e. considerably detached from the principles of the stage.

\section{Document of new social circumstances}

The situation changes when one considers youth and rock music in its different variants. Rock songs, which at least partly used stage rules and then emphatically rejected the previously applicable limitations, began to grow in popularity in the 1980s. One reason for this breakthrough was its social engagement, meaning it responded to the need to describe the reality of young people, diagnose their fears, and to express their rebellion (even if simulated in the case of strictly commercial projects). In the brief introduction to Album polskiego rocka, the brochure's editors wrote:

[About Polish rock lyrics] one can say that they filled the void left by satire, or even artistic song, and they became, in a sense, a document of new social circumstances. We refer to not only lyrics by professionals, but also those crazy young artists, in whose works sometimes excellent ideas competed with low quality scribblings and a lack of writing skills. ${ }^{8}$

Many other opinions share that tone, e.g. the one included in the insert to a punk rock song collection:

Punk rock is formed rather of subcultural hymns than hits. It's a type of a rebellion. It is a manifestation of frustrations or a calculated provocation. Or both simultaneously. It is a style which is intended to irritate. It is ostentatious simplicity and ugliness of sound. And shouting out the ugly truths about our beautiful world. Or that which appears to be those. ${ }^{9}$

That context for the phenomenon offers it the status of a linguistic document of the epoch, and enables one to seek significant linguistic features in rock lyrics after 1980. Halina Zgółkowa shared a similar approach when she was developing the material collected and discussed in an article entitled Językowy obraz pokolenia, czyli o języku tekstów rockowych. The acclaimed Poznan-based language researcher noted a specific characteristic. It was:

\footnotetext{
${ }^{8}$ M. Sart and M. Wiernik, Album polskiego rocka, Pomorze, Bydgoszcz 1987, p. 6. [English version translated from Polish].

${ }^{9}$ W. Królikowski, [text in a record booklet] 22 Polish Punk Classics, SON 23. [English version translated from Polish].
} 
the programme-based approximation (or even association) of rock lyrics with the everyday language of rock fans. Let us (...) quote W. Chełstowski: "Those people use the same language with which they communicate, and with which those for whom they sing communicate." In fact, it is necessary to indicate the mutual flux of linguistic phenomena between the rock and the colloquial versions of the language of that generation. Through those processes, rock Polish, constituting a reflection of colloquial Polish, acquires a significance which is much greater that one could have expected if one considered it only a linguistic tool used for a specialised circle of people. Therefore, the language revealed in rock lyrics can be considered as probably the most accurate reflection of the language of the generation. ${ }^{10}$

The article was published in 1989, and it offered the perfect division enabling one to view the achievements of rockers after a decade of strong presence in public life, and on the eve of major social changes which were only just achieving momentum.

Before that, though, it is worth mentioning one more article by Halina Zgółkowa from 1988 entitled "Miny na pokaz, czyny za grosz..." O tekstach polskiego rocka ${ }^{11}$. There she noted the general tendency among rock musicians to use colloquial vocabulary, jargon, or even vulgarisms (rarely substituted with euphemisms). Based on a linguistic overview, she identified two key reasons for such a situation:

The metaphors used therein were not too sophisticated, but they consistently focussed on two meanings: (1) the vexatious everyday lives of Poles in the crisis of the 1980s, and (2) the restored anti-aesthetic poetics and aesthetics (so vivid after the 1956 crisis). ${ }^{12}$

The example quoted by the linguist must seem curious from today's perspective (HZ's italics). They constituted the violation of previous norms which, until Polish rock boomed, defined the limits of acceptability of the low style and common speech in songs:

\footnotetext{
${ }^{10}$ H. Zgółkowa, "Językowy obraz pokolenia, czyli o języku tekstów rockowych”, Polonistyka 1989, issue 6, p. 448. [English version translated from Polish].

${ }^{11}$ H. Zgółkowa, “"Miny na pokaz, czyny za grosz...' O tekstach polskiego rocka”, in: Język zwierciadtem kultury, czyli nasza codzienna polszczyzna, collective work edited by H. Zgółkowa, Wydawnictwo Poznańskie, Poznan 1988, pp. 69-83. [English version translated from Polish]. The book also included other interesting texts on the topic being discussed, e.g. H. Zgółkowa, K. Szymoniak, „Słowa chore od słów” - czyli polscy rockmani o języku, pp. 84-97, H. Zgółkowa, K. Szymoniak, Prowokacja czyli o nazwach polskich zespołów rockowych, pp. 98-109. To offer a summary would exceed the modest frame posited for this text, however, they constituted material I consider an invaluable basis for assessing the condition of the language (lyrics) of the epoch.

${ }^{12}$ Ibid., p. 76.
} 
"I po tyłkach batem bije nas" [so whips our asses], "Już was w swoje szpony dopadt szmal" [Cash has got you in its claws], "Nie trzeba było znów z gaci robić fraka" [You shouldn't have made a tailcoat out of pants], "Zawodowi macherzy od losu" [Fate professionals], "W oczy patrzy mi twarz, że aż $w$ mordę dać" [A face looks into my eyes, so much that I should punch it], "Jakoś ze mną przebiedować" [Weather it with me], "Już z ogonków wycofały się..." [They backed away from the lines...], "Nie ma jak szpan" [There's nothing better than swagger], "znów wodę zamknął cieć z gwary miejskiej" [the water was shut off again by the caretaker from the urban hustle], "Nikt nam nie podskoczy" [No one can stand up to us], "Lapię kilka $d y c h$ " [I catch a couple of dozen], "Słyszę wyraźnie faceta głos" [I can clearly hear the dude's voice], "Kumpel radio zniósł" [My buddy carried the radio down], "wiatr tarmosi nasze ciuchy" [The wind tousles our rags], "Ty to zawsze masz fart!" [You're always lucky!], "Ciągnie forsę lachmyta" [He makes a lot of cash, that shmuck], "Wyciągasz ostatniego peta" [You take out the last fag], "By nie wyrósł wam bandyta albo świr" [So that you do not raise a criminal or a wacko], "Nie pomogą tu żadne bajery" [No tricks will help here], "na oko margines" [Gutter in my eye], "nie wiem co grane - może lewy business" [I don't know what is going on - maybe some phoney business], "Spokojnie, człowiek - bez nerw i nie pękaj" [Cool, man - chill and don't give in], "Że to wszystko blaga //Że to wszystko pic" [That it's just a bluff / That it's all puffery], etc. ${ }^{13}$

However, the researcher also documented the particularly pungent expressions with comments:

And finally the most disputable commonness, i.e. vulgar and euphemistic expressions and phrases, e.g.: "Znów do wina // Bieży świnia pod nosem kurwa mać" [To wine again // The pig runs mumbling fuck this], "Nie mogę wstać ani spać // Ani siku zrobic" [I can't get up or fall asleep // Or take a leak], "jednak w końcu wciąż wystaje nam // wielkie gole de // gołe de!' [but we are still showing // a big naked a..., naked a...], "nazwałem siebie sukinsynem" [I called myself a son of a bitch], "takie wulgarne i zblazowane" [so vulgar and jaded], "stęchła chcica od nich czuć" [they reek of stale want], "W małych mózgach tylko chuc" [In small brains there is only sexual desire], "Mówią psychiczny, o mnie mówią" [Crazy they say, they say about me], "Czuję dłoń, która pieści // Okolice gdzie mam wstyd” [I feel a hand caressing // There where my shame lies], "Ręce nieruchomo ujęte są w biały płaszcz // Co rękawy w supet z tytu ma" [Hands motionless bound by a white coat // Which has its sleeves tied behind], "Hej, spragnione supersamce" [Hey, you eager supermales]. ${ }^{14}$

\footnotetext{
13 Ibid., p. 74.

${ }^{14}$ Ibid., p. 75.
} 
Today's readers accustomed to quite different linguistic freedom may rub their eyes in amazement at what expressions were considered as violating previous norms. Those examples came from official publications, which is why the emotional amplitude expressed in the language was not subject to such exaggerations as in uncensored cases. Those were, in fact, the first to break previous linguistic norms, with new communication objectives which songs had begun to fulfil.

Zgółkowa later investigated texts which had not been officially published. That study resulted in the previously mentioned article Językowy obraz pokolenia, czyli o języku tekstów rockowych. When defining the selection of the material, the linguist wrote [my emphasis]:

All the used lyrics were taken from the archives of the Jarocin rock festivals of 1984-1987. Those were unpublished texts (some would have probably had considerable problems with censorship due to moral considerations). The study material was taken from fewer than 900 lyrics of various lengths. Should one compare this corpus of lyrics with the official ones (published in youth magazines, broadcast on radio shows, and in the form of records propagated officially), one would clearly notice a distinct difference between the categories. That difference also applies to the linguistic layer, particularly the lexis, and is expressed in, e.g. the level of saturation of lyrics with obscenity, the presence of syntax-phraseology templates, and finally the frequency of the presence of structures violating the norms of correctness. ${ }^{15}$

Therefore, the perception applied to unpublished works which remained outside the official language, though which aspired to it due to the form in which it was provided. Zgłókowa noted:

Amateurs who wrote the lyrics collected in the Jarocin archive clearly favoured strong linguistic accents. Those strong words were mainly vulgarisms. In some lyrics, their accumulation reached the limits of receivers' immunisation or indifference as vulgarisms which are used often lose their power to shock, they become tamed and assimilated. The examples are not exceedingly interesting since it is simply an index of gutter words appropriated from there, and transferred to quasi-literary texts. Here are said words with their context: "dajcie ognia kurwy" [give some hell, bitches], "Ty stara kurwo gin //ty Burek sraj jej w ryj" [die, you old whore // go on, Burek, shit in her gob], "ogień pali, dym zacina, stare babsko w gacie sra" [flames burst, smoke rises, the old hag is shitting in her pants], "nie jestem faszystą ani skurwysynem" [I'm neither a fascist nor a son of a bitch], "wyje w kłębach dymu rozchełstana zdzira" [undressed whore is screaming in clouds of smoke],

\footnotetext{
${ }^{15}$ H. Zgółkowa, “Językowy obraz...”, p. 443. [English version translated from Polish].
} 
"wchodzących w ten syf" [those entering this crap], "idzie szmata ulicą // myśli że jest dziewicą" [a slut walks down the street // thinking she's a virgin], "niech się wszyscy ode mnie odpierdola" [may everyone piss off], "nie dłub we mnie ty skurwielu" [don't pick on me, you fucker], etc. ${ }^{16}$

Therefore, the linguist concluded that it would be futile to seek linguistic originality while words taken from slang remain unchanged and not enriched. Thus, one could say that the freedom utilised by young artists does not offer the desired linguistic effects, leads to backward use of existing means, and not attesting to one's artistic development. However, that applies to a certain subcultural circle.

Therefore, the above summary indicates which differences existed between regular linguistic practices outside the reach of censorship and those which were allowed into the mainstream media and culture of the PRL. In a situation where obscenity had only begun to appear in the public space (e.g. in films: from the cinema of moral concern to the 07 zgloś się television series), still constituting a form of provocation, obscenity formulated from the stage had an undertone of disagreement with censorship, provocation, and a rejection of the applicable norms. Considering the themes of the lyrics, and the air of authenticity, which was the basis for understanding, the linguistic naturalism required one to utilise such means of expression.

In Język subkultury punków, Marcin Lewandowski wrote:

The language of punks is generally considered a variation saturated with obscenity. That thesis could undoubtedly be confirmed by a brief analysis of the semantic and lexical groups. In almost all of them, there were expressions which violated a linguistic taboo, which were used to express emotions towards someone or something. Punks' lexical repertoire included both words considered indecent regardless of their semantic characteristics or the contexts in which they appear (e.g. pierdolić [to fuck], kurwa [whore], chuj [dick]), and words which are tabooed only in specific meanings which usually refer to parts of body or physiology (e.g. heblować [to fuck], rżną́ [to fuck hard], drut [dick]). ${ }^{17}$

The author went on to find the reasons for the common presence of obscenity in the language of that social group. He mainly identified the intentional violation of a linguistic taboo as a manifestation of a moral-stylistic provocation, contestation of language against the existing norms and values, and a sign of the times. He proceeded to emphasise the complex nature of the meanings of vulgar expressions,

\footnotetext{
${ }^{16}$ Ibid., p. 445.

${ }^{17}$ M. Lewandowski, Język subkultury punków, Wydawnictwo "Poznańskie Studia Polonistyczne", Poznan 2007, p. 87.
} 
inferring a representation of a wide range of feelings ("on the one hand: aggression, hatred, rage, rebellion, fright, resignation, disillusionment, and, on the other: amazement, joy, astonishment, and excitement") from their homonymous nature. "It is, therefore, incorrect to consider the use of vulgarisms solely as an attempt to express only negative feelings," concluded Lewandowski, as much in reference to the language of the punk subculture, as to the contemporary language in general. In fact, a similar intention has been shared by rappers, who for several decades now have participated in the culture between unofficial and mainstream media.

\section{This is our culture}

The important change resulting from the cultural reassessments of the turn of 1990 nullified old norms and introduced its own principles of communication. From today's perspective, it is clearly visible how the availability of the means of the distribution of culture enjoyed by the new generation has altered things irreversibly. One outcome of the opening of mainstream media to new trends was the permeation of the once subcultural norms into general circulation. An excess of experiences was ensured by a crash course on post-modernism, which had already been well-established in the West, and entered Poland with an impetus in the 1990s. While trying to consider all the social and cultural factors which influenced the expansion of obscenity after 1989, one needs to remember about the liquidation of GUKPiW (Chief Control Bureau for Press, Publications and Performances), which was formally dissolved in April 1990, but from the summer of 1989 had fulfilled virtually none of its censorship functions. Throughout the decades of protecting the system, censorship also shaped moral norms. Therefore, it was natural that once liberated from its oppression, people began to test the limits of the available linguistic possibilities.

For society, the 1990 s were a period of cultural shock, and particularly distinct reassessments which played out within the realm of popular culture. The times I am referring to saw the release of Władysław Pasikowski's blockbusters, first Kroll and then Psy. The films, with their plots depicting a watershed period, and the sickness within the post-communist special police, used linguistic vulgarisation as one of the major elements for constructing their reality. The following is a fragment of a typical review from the Gdansk film festival in 1992, which discussed the impression the film made on the reviewer:

The language which the people in film use is deficient and foul. I will probably not hear so many words beginning with $c h, k$, and $p$ within the next three months as I did in the festival theatres within the last week, though I do not shun away 
from contact with the grey areas of reality. In the already famed Psy, all dialogues could be written using a single verb and a single feminine noun. The Polish record remains safe. ${ }^{18}$

From today's perspective, the evaluation seems somewhat unidimensional, particularly if one considers the potential the dialogues of the film offered language users to absorb a multitude of so-called cult quotes (kultowy tekst - the term is being ousted by the term winged words), which were not just limited to vulgar expressions. In truth, though, films have become an important element of both recording and sanctioning new linguistic norms, which have in a completely unhindered way gained their place within society. The acceptance of the models coming from across the ocean (the entertainment-based approach to brutality and violence, with the support of linguistic material, making reality more probable and attractive) as the dominant culture has only amplified the general tendencies in the Polish culture of the turn of the $21^{\text {st }} \mathrm{c}$.

\section{Punk's Not Dead}

It seems that in the case of the above-mentioned process, the subcultural youth community has had a key significance. Stemming from the achievements of the counterculture, standing against the existing trends, they exerted the greatest influence on the shaping of the sensitivity associated with contesting all existing norms. It was also the basis for the formation of the linguistic habits of the later elite: artists from various areas (musicians, writers, poets, actors, film makers, journalists, and, finally, television and radio chief editors, etc.) A considerable group of people who gained a voice after 1989 have defined their roots precisely within the space contesting the official culture circulation and favouring diverse independent scenes, together with their subcultural bases. Language had to fall as one of the victims of such a revolution.

It did not, of course, mean that the new cultural elites of the early Third Polish Republic came solely from communities which abused vulgarisms. The issue lies in the fact of the shift of moral norms, the approach to taboo in language with the inevitable generation change. That revolution first happened in the widely considered underground community, later, along with the new social order, it gradually found its place within the space of the official culture. For the generation which entered a reality liberated of any censorship limitations, carrying a morality de-

${ }^{18}$ As cited in: H. Wiśniewska, “Co począć z wulgaryzmami”, in: Polonistyka 1994, issue 2 (312), p. 82. [English version translated from Polish]. 
veloped in various subcultures, it was a natural space of linguistic and cultural freedom, which was utilised to the fullest. ${ }^{19}$

Within the culture of the 1990s, Marcin Świetlicki has become known as an artist who skilfully combined the roles of a poet and a lyric writer, and a rock artist (the term singer somehow does not fit here). Due to the qualities of his poetry and the popularity he gained thanks to stage performances, for many years he was the representative of the poetry of the new time, a generation which entered official literature after 1989, in the role of a rebellious thirty-year-old. An air of scandal was amplified by the popularity of Nieprzysiadalność, a work in which one particular phrase was the most absorbing:

Ja to pierdolę, dziś jestem w nastroju nieprzysiadalnym.
Fuck this, today I'm in a

don't-sit-by-me mood. ${ }^{20}$

And even though the poet himself stressed that obscenity was not a means of expression often used by him, it is worth remembering the axiological shifts due to which today's criteria require one to treat as vulgar speech an extensive collection of lexis, which not that long ago was located in lower registers. Świetlicki also capitalised on the popularity he gained as a representative of the new language in poetry after 1989. It was in that poetic formation that the tendencies for linguistic barbarity appeared, while a poem by Zbigniew Sajnóg entitled Flupy z pizdy, which through its terseness and original obscenity constituted an easily

${ }^{19}$ It is not the intention of this study to reflect on the vulgarisation of the language. However, in the works of linguists of all decades, one could notice a continuing consideration and concern for the gradually progressing devaluation of moral norms. I am referring to articles which cannot be summarised in this text, but which constitute a fascinating read on the recording of social changes reflected in the language, e.g.: M. Kita, "Ekspansja potoczności”, Prace Językoznawcze 19, Studia polonistyczne, A. Kowalska, A. Wilkoń (eds.), Katowice 1991, Prace Naukowe Uniwersytetu Śląskiego 1178, pp. 83-90; J. Kowalikowa, "Znaczenie i funkcja wyrazów tzw. brzydkich we współczesnej polszczyźnie mówionej” (pp. 107-114), and M. Schabowska, "Funkcje elementów potocznych we współczesnym języku oficjalnym” (pp. 67-72), in: Współczesna polszczyzna mówiona w odmianie opracowanej (oficjalnej), Z. Kurzowa and W. Śliwiński (eds.), Universitas, Krakow 1994; H. Wiśniewska, “Co począć...”, pp. 82-86; W. Lubaś, “Rola słownictwa potocznego w polszczyźnie ostatniego dziesięciolecia” (pp. 59-68) and J. Mazur, M. Rzeszutko, "Słownictwo 'NIE' jako przykład agresji i wulgaryzacji języka we współczesnej polszczyźnie” (pp. 149-160), in: Stownictwo wspótczesnej polszczyzny w okresie przemian, J. Mazur (ed.), Wydawnictwo Uniwersytetu Marii Curie-Skłodowskiej, Lublin 2000; “Życzliwość i agresja w języku i kulturze.” Język a kultura, vol. 17. Wroclaw, 343 pp.; M. Grochowski, Słownik polskich przekleństw i wulgaryzmów, Wydawnictwo Naukowe PWN, Warsaw 2008, 240 pp. Interesting literary science analyses regarding the relationships between the language of literature and social reality which provide insight into the matters discussed herein were offered in, e.g.: S. Barańczak, "Zemsta na słowie. O 'Balu w operze' Juliana Tuwima”, Zeszyty Literackie 1983, issue 4, pp. 95-111; E. Balcerzan, "Brzydkie słowa w literaturze pięknej”, Nurt 1966, issue 4, pp. 34-35.

${ }^{20}$ M. Świetlicki, Wiersze, EMG, Krakow 2011, p. 159. [English version translated from Polish]. 
repeatable example of the tendencies present in literature after the transformation, has become a literary legend:

$$
\begin{aligned}
& \text { mam flupy - usłyszałem } \\
& \text { od dziewczyny i myślę: co? } \\
& \text { - co? - pytam } \\
& \text { - no, leci mi z pizdy }
\end{aligned}
$$

$$
\begin{aligned}
& \text { I've got dingles - I heard } \\
& \text { from a girl and I'm like: what? } \\
& \text { - what? - I asked } \\
& \text { - well, my cunt is leaking }{ }^{21}
\end{aligned}
$$

Literature and culture alone sanctioned the language which was used increasingly often by the representatives of various social groups.

\section{Kazik}

One of the major music artists of the last thirty years who treated obscenity as a means of expression like any other (if not privileged), is Kazik Staszewski. ${ }^{22}$ Who knows if it was not him who guided the genre towards its present freedom in using obscenity - when viewing the wide perspective of the entirety of communication. Probably the first song which became popular despite its poignant vulgarism included in the chorus was Jeszcze Polska, which spewed critical images of the Poland of the early-1990s. One chorus line is most noteworthy:

What have you, fuckers, done with this land

The entire song is an overwhelming image of the reality of Poland in the first half of the 1990s, which, against people's expectations, did not become a land of universal happiness, while the quoted phrase applied, of course, to politicians. In an overflow of colloquialisms, obscenity is a natural and justified element of the thus presented world. ${ }^{23}$

Kazik used obscenity as a legitimate means of expression, and one could say that he did not approach using it with any particular emotional load. It is an element of common language, and being that, it is located within a linguistic communication which co-forms the lyrics. What was noteworthy was the increase in the frequency of use of obscenity in the lyrics of his solo albums from the 1990s. Considering his four solo albums - Spalam się (1991), Spalaj się (1993), Oddale-

\footnotetext{
${ }^{21}$ Z. Sajnóg, "Flupy z pizdy”, Brulion 1991, issue 16. [English version translated from Polish].

${ }^{22}$ The quotes of Kazik Staszewski's works were taken from respective CD booklets; infrequently, the audio version was compared with official publications or lyrics available on the internet.

${ }^{23}$ More than two decades later, Kazik himself euphemistically referred to his own words singing in Plamy na stońcu: Twenty years later after that song / What have you done and similar laments.
} 
nie (1995) and 12 groszy (1997), which also due to their musical conventions presupposed the use of obscenity, one could see how the author's inclination towards using vulgarity grew within the initial years of the final decade of the $20^{\text {th }} \mathrm{c}$.:

Spalam się (1991):

Dopiero w jej mieszkaniu, nosz kurwa mać

Gdy ona do mieszkania swego szła wolnym krokiem

Jacyś leszcze obili mi ryja pod jej blokiem

(Dziewczyny)

Coście skurwysyny uczynili z ta krainą (...)

Cala jego ciężka praca, wszystko było chuja warte

(Jeszcze Polska)

Spalaj się (1993):

Po co tu przychodzą, do kurwy nędzy, nic tu po nich

(Na mojej ulicy)

Oddalenie (1995):

Jeden z nich był jednak na coś

strasznie wkurwiony

(Błagam was)

Jako biały miał w tej celi totalnie przejebane

Ruchali go w dupę Murzyni nad ranem

(...)

Nie puścił was burmistrz, kurwa, nawet pod schody!

(Komisariat 63)

W ciągłym mroku chlupie jebana hotota

(Nie lubię już Polski)
Spalam się (1991):

It was only in her flat, oh fuck me

When she proceeded slowly to her flat

That some losers beat me up at her block of flats

(Girls)

What have you, fuckers, done with this land

(...)

All his hard work, everything was worth a dick

(Jeszcze Polska)

Spalaj się (1993):

Why do they come here, the fuck, there's nothing for them here

(Na mojej ulicy)

Oddalenie (1995):

One of them was really pissed off

(Błagam was)

Being white in that cell he was really fucked

They screwed him in the ass Niggers in the morning

(...)

The mayor did not let you, fuck, even by the stairs!

(Komisariat 63)

In constant darkness the fucking trash squelches

(Nie lubię już Polski) 
12 groszy (1997):

Dalej jazda do roboty, jebane nieroby (...)

Co to za wegetarianin, co wpierdala schabowe?

(...)

Jak powstają moje teksty, gdy mnie ktoś tak spyta

Zakurwię z laczka i poprawię z kopyta (12 Groszy)

Dzielnicowy koło bramy opierdala podkomendnych

(...)

Niższy stopniem opierdala innych, mniejszych

(...)

Na obraz jaśnie pana kurwa nasrata (...)

Przy niedzieli przy stole, hę, o ja pierdole Dlaczego oddaliśmy się tym świniom w niewolę

(Mój los)

Jak Pamela jebana niepowiększana (...)

"Skurwysyny, ja bym ich zajebal

Gdybym rewolwer tylko miał"

(...)

Ale chuj. A do tego wszystkiego

Słychać $\boldsymbol{t e b}$ żony sąsiada thuczonej przez niego

(Spowiedź Święta)

Chcemy być tacy, jak chłopcy z ferajny Zajebisty film, fajny

(...)

$\mathrm{O}$, kurwa! | 4x

(O, Kuchwa)
12 groszy (1997):

Go on, get a job, you fucking loafers

(...)

What kind of a vegetarian is he that fucking gobbles pork chops?

(...)

How my lyrics are made, when someone asks me that

I fuck them up with my shoe and add a kick

(12 Groszy)

The flatfoot by the door is giving a fucking talking to to his subordinates (...)

The one with a lower rank is giving a fucking talking to to others, lower still

(...)

On the master's picture, a fucker shat (...)

On Sunday at the table, what, oh fuck me Why did we become slaves to them pigs (Mój los)

Like fucking Pamela without a boob job (...)

"The sons of bitches, I would fucking kill them all

If I had a gun" (...)

All is fucked. And on top of that You can hear the neighbour's wife's head being smashed by him

(Spowiedź Święta)

We want to be like real goodfellas Abso-fukcing-lutely great film, cool (...)

Oh, fuck! | 4x

(O, Kuchwa) 
Jak bardzo skurwisz się, by sprzedać swą muzykę?

(Jak bardzo możesz zmienić się, by sprzedać swą muzykę)

Idę spać, a to, do kurwy nędzy, nie o to przecież chodzi

(Nie ma towaru w mieście)

Gdyby było inaczej, to by było

przejebane

$$
\text { (L.O.V.E.) }
$$

I są miejsca zajebiste, i takie gdzie kila To znaczy syf. O tym mówiłem

(Idę tam, gdzie idę)
How big a shit are you ready to become to sell your music?

(Jak bardzo możesz zmienić się, by sprzedać swą muzykę)

I go to bed, and that, fuck me, was not really the point

(Nie ma towaru w mieście)

If it had been any other way, it would all be fucked

$$
\text { (L.O.V.E.) }
$$

There are fucking great places, and those which are shit I mean crap. That's what I was talking about

(Idę tam, gdzie idę)

Obscenity exists as an element of the language which describes the presented world. That shows vulgarisms have become commonplace in everyday language, and there they also appear as one of the linguistic means used for describing reality. The title song from the 12 groszy album was in the top three of the Polish Radio Three hit list for 15 consecutive weeks, including 6 weeks in total in first place. Kazik's hit was also voted The Song of the last 25 Years in the 25 Years of Liberty survey organised by the Świat się kręci show. The winners in other categories included Wojciech Kilar, Marek Koterski, Adam Małysz, Jerzy Owsiak, and John Paul II. ${ }^{24}$

When a vulgarism becomes so common, its functions become supportive for the linguistic context of a song. Therefore, particularly noteworthy are the situations when a vulgarism draws the attention fulfilling a chorus function. In my opinion, that is the case in the chorus of DD:

Będziesz wisial Müller, ty kurwo jebana,

za to że DD się błąka po obcych krajach
You'll hang Müller, you fucking cunt, because DD wanders through foreign states

\footnotetext{
${ }^{24}$ Vide http://wpolityce.pl/media/199000-wybrano-polaka-piosenke-film-i-tworce-25-lecia-wolnosci (accessed on: 23.12.2017).
} 
The direct vulgar reference to another person, in combination with a punishable threat, constitutes a special type of linguistic aggression. Additional meaning should be sought in the phonetic version. The name Müller, anonymous based on its homonymic nature, articulated in the song sounds like Miller, which in turn was the surname of the prime minister of the Republic of Poland, whose presence could be justifiable for social reasons, considering the origins of the work. When referring to the main protagonist, Kazik span a long story. Only the initial and final fragments indicate the author's emotional attitude towards the protagonist:

It is a real person, our fan Didi. We met in the 1990s when Kult were signing records in Empik in Nowy Świat. It lasted four or five hours, and to get a good place, you had to come several hours before. He was always one of the first to come (...) Didi was a contractor. His company was growing, but he lost two important tenders, and he went bankrupt. His family fell apart. He left for Spain. He had a car accident after which he took stock of his life. He stopped drinking, and he started to get back into shape. Currently, he lives in Tenerife, and he is starting a new business. He is a charming smart dude; he is likeable, even my grandchildren love him. Another case of someone who is a good professional, but didn't have the conditions to develop here, and had to set off into the world..$^{25}$

However, the author introduced signals which might indicate that the statements by the poetic persona ought to be considered as the voice of another figure, as if his statements were only the poetics of the role. The rather trite statements:

Taki dobry chłopak a tuła się po świecie

Taki dobry chłopak swego kąta własnego nie ma

To nie w porządku...

Taki dobry hombre musi tułać się po świecie

Taki dobry chłopak tęskni w dalekich stronach...
Such a good boy, yet he wanders the world

Such a good boy, yet he doesn't have a room of his own

That is not right...

Such a good hombre, has to wander the world

Such a good boy longs for distant lands...

seem like a regular nagging of a figure with rather low linguistic competences, and the related limitations in expressing emotions. And yet there is a kind of a game between the senders, as if the performer and the author used a mask of poetics, i.e. by assuming the form of a simpleton, the author tries to say something personal. That game, difficult to settle, may indicate how songs are prone to various interpretations.

${ }^{25}$ K. Staszewski, Idę tam, gdzie idę. Autobiografia, interviewed by R. Księżyk, Kosmos Kosmos, Warsaw 2015, pp. 332-333. [English version translated from Polish]. 


\section{Grabaż}

One of the model representatives of the generation of the transformation era $^{26}$ was Krzysztof Gragowski (aka Grabaż, the leader of Pidżama Porno, though the drummer and the author of the lyrics of Dezerter with the same name would also fit the above description). From the start of his career, he was fascinated with the anti-aesthetic trends in song-writing; he actively engaged in the lives of various subcultures; he violated many linguistic taboos within the stage song aesthetic. In his works over the years, there were several dozen songs in total which included obscenity in various functions. ${ }^{27}$ Here are some examples (in-depth analyses would require broader contexts, but the following quotes were intended mainly to emphasise the frequency, viewing the artistic functions below based on selected examples):

Kurwy i faszyści są w niebie

Wszelkie zło się przez zło zbawiło Józef K. (1984)

Przelecieć się nago po Placu Czerwonym Pokazać goła dupę Stanom Zjednoczonym

Gdy strumyk plynie z wolna (1984)

Mister, you can fuck my sister

She is really pretty girl

Fucking in the church (1989)

Codzienność zaklęta w kwadraty

Figury geometryczne

Te same czerwone ryje w południe

Syreny fabryczne

Codzienność (1989)
Whores and fascists are in heaven

All evil was redeemed by evil

Józef K. (1984)

Run naked acrossRed Square

Show your bare ass to the United States

Gdy strumyk plynie z wolna

(1984)

Mister, you can fuck my sister

She is really pretty girl

Fucking in the church (1989)

Everydayness enclosed in squares

Geometric shapes

The same red gobs at noon

Factory sirens

Codzienność (1989)

\footnotetext{
${ }^{26}$ A term derived from Edward Balcerzan's work was used for the title in a philological discussion by Piotr Łuszczykiewicz with the meaningful title: Piosenka $w$ poezji pokolenia ery transformacji, Poznan 2010. Due to a shift of the emphasis towards strictly poetic works, Krzysztof Grabaż Grabowski was almost completely omitted.

${ }^{27}$ Quotations from Grabaż's works were taken from the book edition of his output (K. „Grabaż” Grabowski, Wiersze, Lampa i Iskra Boża, Warsaw 2008), and in the case of more recent works, from respective $\mathrm{CD}$ booklets.
} 
Pobożne Poznanskie mieszczki rzygajace po thustych golonkach Dramatyczne aktorki jak deski w śnieżnobiałych koronkach Świńska procesja (1988)

I zaznamy jeszcze nieba w naszych mordach

A gdy to się nam nie uda

Wtedy wpierdolimy orła z godła Strzelaj lub emigruj, czyli pieśń głodnego robaka (1988)

Czasem uśmiecham się przez sen, a gdy sen przychodzi zaraz

Śni mi się monstrualna pizda żarłoczna jak kosiara

Film o końcu świata (1988-89)

Stary świat ogłosił krach, permanentnie kona

Kiedy dziwka rewolucja przytuli go do swego łona

Permanentna rewolucja (1989)

Możesz jeszcze uratować siebie

Nim zostaniesz zdalnie sterowaną dziwka

(...)

Macie tepe mordy i wydaje się wam, że Możecie zmieniać świat środkowym palcem

(...)

Gdy obijasz mordę komuś

W oczach masz coś z durnia i coś z Huna

(...)

\section{Szajs, beznadziejny szajs}

Kilka zdań o Hitlerjudend

(1989)
Reverent Poznan townswomen puking with greasy pork knuckles

Dramatic actresses like carrot sticks in snow-white lace

$$
\text { Świńska procesja (1988) }
$$

And we shall taste heaven still in our

\section{mugs}

And if we don't succeed

Then we'll throw the fucking eagle

from its nest

Strzelaj lub emigruj, czyli pieśń głodnego robaka (1988)

I sometimes smile in my sleep, and when I fall asleep right away

I dream about a humongous cunt esurient like a lawnmower

Film o końcu świata (1988-89)

The old world has announced a crash, it is dying continuously

When the revolution slut holds it against her bosom

Permanentna rewolucja (1989)

You can still save yourself

Before you become a remote controlled slut

(...)

You've got dumb mugs and you think that You can change the world with your middle finger

(...)

When you punch someone in the puss

In your eyes, there's something of an ass and something of a barbarian

(...)

\section{Crap, hopeless crap}

Kilka zdań o Hitlerjudend

(1989) 
Oto nasze lekarstwo - nowy cudowny lek

Oto nasze lekarstwo - najpierw

pierdolnij się w łeb Awangarda jazz i podziemie (1990)

\section{Z gardeł za haftem leci haft i cuchna} przepocone futra

Bal u Senatora 93 (1993)

Jesteś dupkiem,

chociaż nosisz dredy

Złodziej zapalniczek (1995)

Całkiem spokojnie jem kolację

Wcale nie chce mi się rzygać

Coca coca hera hera (1995)

Chory bałagan, nic się nie zgadza:

żadna kurwa i żadna mać

Gorzka (1998)

Wściekła Mariola, najbardziej krzywe nogi świata na ulicy pizd

Wściekła Mariola (1996)

Jestem pojebany punkowiec, cwaniak mentalny

Szyderca i głupawiec, ściemniacz seksualny

Moja silna wola - pierwsza lepsza

kurew - puszcza się i łajdaczy

Styropian (1995-96)

Żyję tylko po to, by napierdalać warszawiaków

Prawie każdy z Warszawy jest na głowie swej kulawy

A najbardziej komercyjny jest pies policyjny

Marchef $w$ butonierce (2001)
This is our medicine - a new wonderful drug

This is our medicine - first hit your stupid nut

Awangarda jazz i podziemie (1990)

From their throats they hurl incessantly and those sweaty furs reek

Bal u Senatora 93 (1993)

You're an asshole,

though you carry dreadlocks

Złodziej zapalniczek (1995)

I eat my supper quite calmly

I don't feel like puking, not at all

Coca coca hera hera (1995)

Sick mess, nothing's right: no holy and no shit

$$
\text { Gorzka (1998) }
$$

Furious Mariola, the most crooked legs in the world in cunt street

Wściekła Mariola (1996)

I'm a fucked up punk, a mental hustler A scoffer and an idiot, sexual fibber My strong will - any given whore puts out and carouses

Styropian (1995-96)

I live only to fuck up Varsovians

Almost everyone from Warsaw is crippled in their heads

And the most commercial of them all is the police dog

Marchef $w$ butonierce (2001) 
Swastyki w twojej głowie gorsze niż te na ścianach

To fatalna iluzja

Gówniana fatamorgana

Pryszcze (2001)

Czarną szosą w czarną noc popierdala czarna wołga

Maluję czarne serca na czarnych czołgach

Paint It Black (2001)

Ja mam nabitą faję

W głowie mam cygański zajeb

Cygański zajeb (2003)

Tam gdzie kurwy, grzyby i krasnale

$\mathrm{Na}$ szklankach i na firankach

List do Che (2001)

Same chujowe słowa jak przeżeniony towar

Same chore słowa, po których puchnie głowa

(...)

Poniżej pasa - twa sztuczka nieczysta

To do lisiej pipki z tutejszego

„Aktivista”

Butgarskie Centrum Hujozy

(2004)

Wiesz że nie mam dokąd już stąd

Spierdalać

Spierdalać

Spierdalać

Spierdalać

Pogrzeb Króla (2005)
Swastikas in your head are worse than those on the walls

That awful illusion

Shitty mirage

$$
\text { Pryszcze (2001) }
$$

Down a pitch black road during a pitch black night speeds a pitch black Volga They paint black hearts on black tanks Paint It Black (2001)

I have my pipe prepped

In my head, there's a gypsy craze

Cygański zajeb (2003)

There where whores, mushrooms and dwarfs

On the trails and drapery

List do Che (2001)

Only shitty words like fake stuff

Only sick words which make your head swell

(...)

Below the waist - your dirty trick

It's for the foxy pussy from the local

'Aktivist'

Butgarskie Centrum Hujozy

(2004)

You know I have nowhere to

Piss off

Piss off

Piss off

Piss off

Pogrzeb Króla (2005) 
Jestem jak jaskółka co wiosnę zgubiła I znów zima za dupę mnie trzyma (...)

Dostałem w ryj fajką pokoju

Chory na wszystko (2010)

Za stara do wojska, brudny ryj

$\mathrm{z}$ wąsem

$$
\text { Łąka (2008) }
$$

Czyściciele warg zajęczych odkurzają mnie z pajęczyn

Więc się ich pytam, kurwa, co jest? (...)

Kto $\mathrm{z}$ tego napięcia

pierdolnie ze szczęścia?

Żyję w kraju, w którym wszyscy chcą mnie zrobić w chuja!

Żyję w kraju (2010)
I'm like a swallow that lost spring And once again winter holds my arse tight

(...)

I got hit on the mug with the ceremonial pipe

$$
\text { Chory na wszystko (2010) }
$$

Too old for the army, dirty mug with a tache

$$
\text { Eąka (2008) }
$$

Cleaners of hare lips remove the cobwebs off me

So I ask them, what the fuck?

(...)

Who out of this tension shall fuck up of joy?

I live in a country where everyone wants to screw me over!

Żyję w kraju (2010)

The above examples indicate that Grabowski rather consistently used vulgarisms throughout his creative period - regardless of whether he operated within the independent scene or approached the mainstream, as has been the case in recent years. With such a saturation, is it clear that obscenity, just like in everyday language, has found a legitimate place in songs, maybe not mainstream and massively popular songs, but still, songs the popularity of which exceeds considerably the framework of the niche independent scene.

That set also helps one realise that thus considered vulgarisms may be endowed with various functions, depending on the communication situation the poetic persona creates. In some cases that applies to the poetics of the role, where the language defines the character and reveals his/her primitive nature (Strzelaj lub emigruj, czyli pieśń głodnego robaka, Marchef $w$ butonierce). A similar motivation can be found in the song Styropian, where the set of self-accusations embellished with vulgarisms brings to mind the ironic use of various accusations formulated against the artist by his former fans disappointed in him.

Most often, though, vulgarisms are simple elements of expressions, they merge into the background and the language, without remaining the focus of one's attention (I znów zima za dupę mnie trzyma..., Tam gdzie kurwy, grzyby i krasnale..., Nim zostaniesz zdalnie sterowana dziwka, Czarna szosa w czarna noc 
popierdala czarna wotga, etc.) That is a proof of the linguistic freedom which enables such stylistic choices.

A special case is the emphasising of vulgarisms by placing them in the chorus or other significant locations within a song, which focuses the message around a specific expression. That is the case in such songs as: Butgarskie Centrum Hujozy, Cygański zajeb (the titles), Film o końcu świata, Pogrzeb Króla. In the final case, that consisted of multiple repetitions of the word "spierdalać" [to piss off] with dynamic music in the background, in the finale of a song, which is a surrealistic impression of Poland after the death of John Paul II.

A special role should be reserved for the song closing the above list, i.e. Żyje $w$ kraju, where a significant part of the message is focussed on emphatic vulgarisms. Grabowski's reflection made from the point of view of an artist aware of the need to make decisions regarding the planned (which does not mean it is always fulfilled) fate of a song:

It was more or less like this: there were a couple of people who listened to the initial partial versions of the songs. Everyone said that it was a shame that the song had such words. Because it could had been a dead certain hit, but everyone knew that you could not make a single out of it. And I said: "No fucking way." Even if I would have to stand up to everyone like a dick, it will be a single, the first song. I once again stood up to everyone and I said: "if that's your decision, then screw you." And I realised we were pumping a lot of money into it by simply posting it on the internet. But then, surprise, surprise, radio stations started playing it. And the song started to function. ${ }^{28}$

In a concise manner, Grabaż defined the mechanism which often constitutes the first step towards creating a hit. In the case of a song so saturated with obscenity which offered an attractive music layer, the decision to release a single (i.e. a potential hit for radio stations) was risky, though, as it turned out, not doomed to fail. The phenomenon of self-censorship impels one to start working out what will be most beneficial, yet the final outcome remains unknown. The single sent to radio stations included a few versions, including the so-called single version and the censored single version, where the vulgarisms were suppressed with overlapping

${ }^{28}$ K. Grabaż Grabowski, K. Gajda, Auto-bio-Grabaż, In Rock, Poznan 2010, p. 528. [English version translated from Polish]. Being the artist's interviewer and the person responsible for the final linguistic shape of the quoted interview, I wish to indicate the use of vulgarisms also in the official communication, i.e. the published biographic notes. The interview was conducted from start to finish as a narrative intended for publication, though it was intentionally shaped to exceed the rigid limitations of its official nature. When editing the oral statements for the purposes of a printed text, together with the protagonist of the story we made the unanimous decision to retain the vulgarisms as legitimate elements of the private style of the speaker, and his natural linguistic expression. 
sounds. The stations used the latter most often, which does not cancel the role of obscenity in creating the attractiveness of a message. The outcome was the first place for two weeks on the Polish Radio Three show's hit list, which can still be used as one of the indicators of a song's popularity. The song remained around the first ten on the list for over 10 weeks .

In reference to the above-mentioned examples, one should consider the interesting case of the album !TO! of 2012. Recorded as a particularly anticipated album after the success of Dodekafonia and its hallmark hit (Żyje w kraju), !TO! quite distinctly removed vulgarisms. Grabaż abandoned the characteristic depressive atmosphere, which formed the special undertone to the previous album. Even though it included songs extremely similar in terms of their themes to some songs from Dodekafonia (Bloody Poland, Bankrut, I Can't Get No Gratisfaction, Jesteście gorsi niz wasi starzy, Dreadlock Queen), a different distribution of the emphasis (e.g. the opening and the closing of the album with two songs lighter in terms of their music and lyrics) resulted in the album being considered as much lighter than the previous one. It seems that such was also the artistic intention of Grabowski himself, which aligned with the visual layer of the promotional efforts: unlike in the case of Dodekafonia, which was accompanied by a photo shoot with a very aggressive character, in the case of $T O$, the band appeared in light tones, they were all smiles, and changed in relation to their previous image. Such a message was also reflected in its tamed language. As an example, consider the beginning of the most politically engaged song with an aggressive title: Bloody Poland:

Specyficzny to kraj - o, ja piernicze -

Gdzie najlepiej sprzedają się znicze
It's a peculiar country - well I'll be -

Where what sells best are grave lanterns

Considering the earlier character of Grabaż's works, in the first line one could have expected a much more pungent expression, while the task of emphasising in the rhyme position the term "grave lanterns" surely would not pose any problems for such a seasoned author, had he wanted to do it. It was his intention to apply a euphemism, because that's what the expression "well I'll be" is. One would be hard pressed to find any vulgarisms in the remaining songs, even though they offered various levels of intensity on social themes.

\section{Kukiz}

In December 2015, Paweł Kukiz, a Polish deputy, posted this to his Facebook profile: "And as a 'good night', I dedicate this to the defenders of 'democracy'." He attached to it a video clip of the song Virus sLd, which he recorded in 2004 
as the leader of the band Piersi. The entire song is consistently maintained in the convention of a curse ${ }^{29}$, consider the lyrics:

Jak ja was kurwy nienawidzę

I jak ja wami kurwy gardzę

Jak ja się za was kurwy wstydzę

Gdy za granicę czasem zajrzę

Jak ja się wami kurwy brzydzę

Jak ja was dobrze kurwy znam

Jak ja się bardzo ludziom dziwię

Którzy wybrali taki chłam

To wszystko czego się dotkniecie

Od razu obracacie w pył

Szarańcza przy was to jest bajka

Bo cały kraj już zgnił

Rozpasłe mordy, krzywe ryje

Kurestwo wszędzie tam gdzie wy

Jak ja was kurwy nienawidzę

Jak do was bym z kałacha bił

A nawet jak wam plunąć w twarz

To wy mówicie że deszcz pada

Jebana wasza partia mać

Co mi ojczyznę okrada

Nadejdzie kiedyś taki czas

Za wszystko kurwy zapłacicie

W helikoptery wsadzę was

I nigdy już tu nie wrócicie
Oh, how I hate you, you fuckers

And how I despise you, you fuckers

Oh, how I'm ashamed of you, you fuckers

When I pop abroad

Oh, how I'm disgusted by you, you fuckers

Oh, how well I know you, you fuckers

Oh, how I'm surprised by people

Who elected such crap

Everything you touch

You turn into dust

Locusts are fairy tale creatures compared to you

Because the whole country is rotten

Fat mugs, ugly yaps

Fuckedness everywhere you are

Oh, how I hate you, you fuckers

How I would spray you from an AK-47

And even if someone spits in your face

You say it's raining

Your whole fucking party

That robs my homeland

There will be a time

You will pay for everything

I'll put you on helicopters

And you'll never come back ${ }^{30}$

Those who expressed outrage at the post mainly focussed on the change of the social position from which the former musician sent his messages. Being

${ }^{29}$ The convention brings to mind the famous martial law poem by an anonymous author entitled Bluzgi (aimed at Gen. Jaruzelski), popularised thanks to a performance by Emilian Kamiński at Teatr Domowy, and propagated on second circulation cassette tapess.

${ }^{30}$ As quoted in http://www.tekstowo.pl/piosenka,pawel_kukiz,virus_sld.html (accessed on: 13.12.2017.) [English version translated from Polish]. 
a deputy, he should be bound by different moral standards than a punk rock musician. However, there was also another important characteristic: the fact of directing vulgar speech at a specific figure, social group, or a community. Originally, according to its title, the song was designed against the governing party at that time; years later, it was used as a weapon against the manifestations of the Committee for the Defence of Democracy (KOD). Such a directional use of obscenity seems more aggressive, and in violation of social norms, rather than just a cultural threat to the abstract notion of language.

\section{Spięty}

Based on the previously discussed examples, one will see that in recent decades, obscenity in songs has been the main carrier of aggression, and negative and contestational content indicating the negative attitude towards the existing social order.

An example of a more complex game with obscenity is offered by the works of Hubert Spięty Dobaczewski, the leader and the author of the lyrics of Lao Che. ${ }^{31}$ Even though in individual songs obscenity is not placed as the main focus, it draws one's attention to the author's output, and it is a constantly present element of linguistic reality. Spięty uses vulgarisms regularly, though they are intertwined within an unclear and ambiguous context of playing with conventions (musical, linguistic, and cultural). In his works, words often surprise each other, and that also applies to indecent expressions.

Powstanie Warszawskie was the album that helped the band become popular. The artist must have been aware of the fact that in such cultural circumstances vulgar expressions may prove particularly controversial, which is why he used them thoughtfully, though boldly. The linguistic image of the whole was influenced by the deconstruction of the language of the period through various collages, which also introduced extensive vulgarity drawn from various linguistic sources.

The album's opening song Przed burza seems entirely put together from quotations, and fragments of reality. By introducing theatricality, it reproduces the atmosphere among the partisan forces within the final moments prior to "W" Hour (an intentional disruption of such a simple placement in time is an inclusion from a song from the 1980s). These are the fragments of the language one could find there:

\footnotetext{
${ }^{31}$ The quotations from Dobaczewski's works came from the booklets of respective CDs.
} 
Wolność ja kocham i rozumiem, wolności to ja oddać nie umiem. A kajdany mi dzwonią, gdy cień Gapy nad głową,

Czas, by powstać i rachunki wyrównać krzywd,

Nazistowskiego by ducha wypierdolić, "Mamidła z wąsikiem" marionetki, Nie wyjdzie stąd żywa psia-jucha parszywa

\section{... kurwa Wasza Faszystowska Mać.}

Freedom I love and understand, freedom, I cannot give up. And the shackles jangle when the shadow of the Nazi Eagle's overhead, It's time to rise up and settle the scores, To fuck the Nazi spirit,

"The mirage with a tache" of the puppet, Will not leave this place alive that lousy dog shit ... kurwa Wasza Faszystowska Mać.

The mixing of quotes from various cultural levels resulted in a clash of poetic pathos with the hilariously archaised soldier talk. The theatricality (through the use of a radio show convention) conducted in a post-modernist collage version utilising samples and various musical styles, engulfed the entire album, which is why the moderately used vulgarisms constitute an element of continuously independent speech which dissipates the opportunities for defining the text's sender. Considering the album's historic nature, the singer/performer of the songs is intentionally more of an actor playing various roles than the author's alter ego. Thus, he also distanced himself from any vulgar expressions, treating the entire message as someone else's words, though specifically his own. The vulgarisms, then, were selected in such a way as not to shock, and to correspond to the linguistic culture of the epoch, subject to brutalisation by the unique situation of the eye of the storm of the war. Therefore, they assume not as much an expressive function as a parody or, more broadly, comical function co-creating the cultural confusion in which Powstanie Warszawskie plays out:

Gar gówna tym gównoryjom i pratyczek w nos,

rykoszet rozpieprzyl zbożówki termos, pale papieros papieros papieros papieros papieros,

los los los barykado nasza Polsko mała!

Idź Pod Prąd!

Na barykadzie, na Rejtana, jeden, drugi bedzie $\boldsymbol{w}$ portki rżnąć,

w portki rínąć, w portki rínąć!

Żaden to wstyd, wszak wszyscyśmy tutaj wiarą dusz.

Polka na RKM i granaty...
A pot of shit for those shit-eaters and a snap on the nose,

A ricochet fucked up a flask with vodka, I'm having a smoke a smoke a smoke a smoke a smoke, fate fate fate our little barricade Poland! Go Against The Current!

To the barricade, as Rejtan did, one, two will shit his pants,

shit his pants, shit his pants!

There's no shame in that, we all are here a legion of souls.

A Polish girl to the chatterbox and grenades... 
The communication chaos filtered through the sensitivity of contemporary man, and the multi-code nature of the genre with the use of the potential offered by the music layer of a song was present in Zrzuty. The following are fragments of the song, which are to indicate the linguistic mosaic, with the highlighted final vulgarism:

...halo, halo tu Londyn...

(...)

Nie nasza rzecz, nasza rzecz naszą robić rzecz.

Ferfluchten polnischen, polnischen Partizanen, banditen, banditen.

(...)

Halo, halo, tutaj Londyn, tutaj Londyn

Ona czarna, a on blondyn, a on blondyn (...)

Myślę sobie, zważ robaczku w czym

się moczysz,

Trach, pif, paf, bum i do Bozi i do

Bozi

["Bardzo pilne, bardzo tajne. Do prezydenta Rzeczypospolitej Polskiej, wysyła Łubieński, początek...”]

(...)

Stuchaj Londyn, nam nie trzeba audycji,

My żądamy amunicji!

(...)

Jak tam u was? - jest spokojnie jak na wojnie,

tu pierdolnie, tam pierdolnie i znów spokojnie.

Yes, yes, yes!

All right, haha!
... copy, copy, this is London speaking...

(...)

That's not our thing, our thing is to do our thing.

Ferfluchten polnischen, polnischen

Partizanen, banditen, banditen

(...)

Copy, copy, this is London speaking, this is London

She's black, he's blonde, he's blonde

(...)

I think to myself, consider, little maggot, what you're soaking in,

Crack, bang, bang, bam, and meet the

Lord, and meet the Lord

[ "Very urgent, very urgent. To the president of the Republic

of Poland, from Łubieński, beginning...”]

(..)

Listen, London, we do not need radio shows,

We demand ammo!

(...)

How are things? - it's peaceful like

during a war,

a bitch of a blast here, a bitch of a blast

there, and the rest is quiet.

Yes, yes, yes!

All right, haha! 
In the audio version, the articulation, due to the distribution of stresses, brings the meter close to chanting. The inclusions from other languages resemble the circumstances of a radio watch, where various frequencies, shows, and messages blend. It comes as no surprise that such a narration includes both a short soldier's exchange of thoughts and a humorous one. Considering the tragic nature of the historic context inscribed in the whole album, such inclusions together with the English expressions concluding that quote offer bitter irony, and not an instance of a mindless game.

On the Gospel album, the mechanism of lowering the style to one which is excessively common has a holistic form strongly associated with the intention of violating the zone of the sacred. In a diverse way based on a multi-code nature, the album raised the issue of the Man - God relationship. Expressions verging on being vulgar, and those actually vulgar, become elements of such a strategy, though it does not possess the characteristics of a confrontational provocation.

Bo ja myślałem, że tu będzie inaczej,

A tu jest tak-o! do dupy raczej,

Jeśli masz w tym frajdę, aby rzeczy gmatwać,

To mi teraz za tę moją krzywdę zapłać!

Bóg zapłać!!!

(Bóg zapłać)

Bo wiesz, miałem ambicje stworzyć rezolutną rasę.

A wyście to tak po ludzku spartolili. Jestem piekielnie sfrustrowany...

(Hydropiekłowstąpienie)
Because I thought, it'd be different here, And here it's like this! rather crappy, If you find joy in complicating things, So pay me now for my loss!

Praise be to the Lord!!!

(Praise)
Because, you know, I had an ambition to create a resolute race.

And you buggered it in your human way. I'm frustrated as hell...

(Hydropiekłowstąpienie)

In the second example, there is a euphemism, but if one realises that it came from God's monologue to Noah, the commonness assumes the characteristics of (humorous) vulgarity.

Spięty's first and only solo album entitled Antyszanty offered an area for free stylistic experimentation, which, among other things, consisted of the language, including vulgarisms, though there as well they were justified with a constant game between the sender: the artist - performer - author - and various characters, which could be assumed thanks to the poetics of the role. By utilising the achievements of comedy and stage songs, Dobaczewski assumed the roles of characters for whom such a language could be justified. In many cases, he verges on coarse obscenity: 
Mori, mori czorno mori, mori memento.

Od wszystkiego się odwrócić może i spierdolamento?

Roboty tu dla ciebie może nie być, fuck off polish scum.

A gdybyś tak może odpieprzyć ode mnie się chciał?

Może i stuknięty był, ale motor igła zdrowy,

Może czasem warto mieć ambicje, co by być chujowym?

(Morże)

Mele kalikimaka jak tak powiesz komu,

Kulas w trawie $\boldsymbol{k} \boldsymbol{u p} \boldsymbol{e}$ mija, ululany $\boldsymbol{l u j}$ trafia do domu.

(...)

Mele kalikimaka! Żeby się panu z tą dużą blondyną ułożyło,

Żeby pani ta kiecka tak nie piła, Żeby wam dzieciaki nie pi...

Żeby ludzie się kochali, a nie napierdalali.

(Kalikimaka)

O! kontradmirały, bosmany, majtki, Porwany żagiel lata jak portowej dziwce majtki

(Trafiony / zatopiony)

\section{Ahoj!}

Nie ma to jak gorąca cipka i jeden głębszy.

(Opuszczone porty)

Nie wiesz ty - czy wieszcz ja, czy ciota?

Melduję posłusznie - idiota

A był raz kapitan, się silił na
Mori, mori czorno mori, mori memento. Turn back on everything maybe and pissoffamento?

There may be no work for you here, fuck off Polish scum.

And if you could fuck off kindly?

It might had been crashed, but the engine's top notch - sound, Maybe sometimes it's worth having the ambition to be a dick?

(Morże)

Mele kalikimaka when you say to someone,

Leg misses the crap in the grass, the sleeping bum finds his home.

(...)

Mele kalikimaka! Hope you get along with that blonde,

Hope your dress gets looser, Hope your kids don't pis...

Hope people start loving each other not fucking up.

(Kalikimaka)

Oh! Counter admirals, boatswains, deckhands,

The torn sail billows like a port whore's pants

$$
\text { (Trafiony / zatopiony) }
$$

Ahoy!

There's nothing like a hot pussy and a shot.

(Opuszczone porty)

Don't you know - whether I'm a bard or a queer?

On your command - an idiot.

There was once a captain, he tried hard 
dydaktykę,

Jak pizdnat $\mathrm{w}$ molo, nabrał wody

i spalił elektrykę.

(Dworujże)

Płyniemy, płyniemy z Jokohamy, Kotwę rzucamy i szczamy w bramy (Łódź wariatów) to instil good teaching,

When he struck the fucking pier, he took on water and fused the wiring.

(Dworujże)

We are sailing, we are sailing for

Yokohama,

We're dropping the anchor and pissing in the passages

(Łódź wariatów)

Łej-hej, chłopcze do rej, / Puszczaj

fiuta - wciągaj buta.

(...)

Hard, hard, boy, to the yard, / Let go of your prick - pull on your shoe.

(...)

Rzekła maszynowni znajoma szprech-rura,

Że mnie z kosą chce ożenić jedna suka

bura,

Ale jak chłop nie je miętki, nie gamoń, nie pizda,

To na przemijanie chłop takowy gwizda.

(Bajka o śmierci)
The friendly voicepipe said to the engine room,

That some dun bitch wants to introduce me to her blade,

But when a man doesn't eat the catnip, he's not a loser or a cunt,

That man doesn't give a shit about passing.

(Bajka o śmierci)

Even there, there are natural contexts, which enable artistic justification of the vile speech. The language of Antyszanty, rocked like a pirate ship, creates a particular environment for various peculiarities, where vulgarisms constitute an element of folk nature, and the low provenance of the seaman genre. Indecent words are also a form of fulfilling the postulate of being anti-genre. Shanties in their codified form rather bring to mind decent lyrics, while excess use of vulgar expressions constitutes a disruption of the original communication situation. Thus understood, vulgarisms also support the parodist function of the entire material.

In "Na końcu języka" from the Soundtrack album, there plays out a competition between vulgarisms and euphemisms:

Są słowa, co je chłopaczyna na murze maluje,

Że policja jest brzydka, a Ala $w$ siusiaka caluje.

(...)

Rzeknie kto: oczy ci wydrapię,
There are words that a boy paints on a wall, That the police are bad, and Ala kisses on the willy.

(...)

Someone might say: I'll scratch your 


\section{boś jest skurwysynem!}

To wciąż nie potrafię poprosić, by zamienił słowo z czynem.

(Na końcu języka) eyes out, 'cause you're a son of a bitch! And I still can't ask him to turn his words into action.

(Na końcu języka)

Such a punchline is the result of broader meta-linguistic considerations devoted to the ability to express one's own thoughts and emotions using words. The essence of those works is the constant confronting of our linguistic experience with added meanings, which sometimes leads to rebellious devices. A linguistic provocation leads to drastic operations, which violate the principle of good taste. In "Jestem psem", there is a passage:

Jestem psem,

Suka matka ma kryta championem. (Jestem psem)
I'm a dog,

The bitch mother of mine mated with a champ.

(Jestem psem)

When out of context, that passage should arouse outrage. If one, however, realises that it is closely related to the anthropomorphisation of the speaking persona, i.e. a dog, the initial reaction subsides and is replaced by a natural linguistic experience, which says that a bitch is a female dog, and it does not need to evoke any negative associations entailed by the vulgarising usage, though, of course, the artist's intention was to stimulate the receiver's sensitivity.

The Dzieciom album displays consideration for a particular understanding of the rules of decorum. Despite its title (For Children), it was developed for adults. However, since its author utilised narration styled to mimic children's culture, the album fluctuated between the two areas. Spięty, having often proven that he knows the low and the very low speech very well, on that occasion decided to use such an expression, which every toddler would be able to use intentionally or unwittingly.

Dzięki za radę Dżinie,

Na nic ona zda się.

Pakuj dupę w lampę,

Skapy grubasie.

(Dżin)
Thanks for your advice, Genie, It's worthless anyhow.

Put your arse back in the lamp, You cheap fatso.

(Dżin)

That is an instance of an intentional disruption of the levels of communication: the tale of a mysterious spirit, usually enveloped in an air of mystery and the related loftiness, is confronted with colloquial language, not obscene, yet vulgar. In "Wojenka", the same expression is compared with a not-so-distant archaism, which pacifies emotions: 
Żołnierz na froncie gnije w okopie, żona pisze: brzuch duży i mały

kopie...

Myśli żołnierz - w dupie $\boldsymbol{z}$ wami

i waszymi wojnami.

(...)

Gdyby do nas przyszła,

zeby ja zaraza ścista,

(Wojenka)
The soldier rots in a trench on the front, the wife writes: belly's big and the boy is kicking...

The soldier thinks - the fuck with you and your wars.

(...)

If it came to us, plague on her,

(Wojenka)

That expression, apparently considered as absolutely benign in the selected narration, appeared a few more times throughout the album:

Wył do księżyca wydłubując $\boldsymbol{z}$ dupy śrut.

(...)

www.dupka jak rzepka chrupka

(Z kamerą wśród zwierząt buszujących w sieci)
He howled to the moon picking pellets from his arse.

(...)

$\boldsymbol{w w w . a r s e}$ crunchy as a turnip

(Z kamerą wśród zwierząt buszujących w sieci)

Sometimes there appear euphemisms, which are to additionally confirm the author's awareness of the communicative principles:

Niemoc goni niemoc, ale pomiędzy:

Wszystkie kolory tęczy do urwy nędzy.

(Errata)

Na dole wśród smoły,

Niezdaluchy i pierdoły,

Na górze Jezusy

I ich lizusy.

(Tu)

I wszyscy myśleli, że to Echo grało,

A Echo $w$ ciula grato, igrało i łgało.

(...)

Miś który nie jest misiem typu

D.U.P.A.

[Bajka o Misiu (tom I)]
Powerlessness on top of powerlessness, yet between:

All the colours of the rainbow, uck me.

(Errata)

Below in the tar,

Failures and berks.

Jesuses above

And their toadies.

(Tu)

And everyone thought that Echo played, While Echo fucked around, toyed and lied.

(...)

A bear not of the A.R.S.E. type.

[Bajka o Misiu (tom I)] 
As indicated through the example of Spięty, obscenity can also be the focus of linguistic games. Those, in turn, in a much broader sense, in the olden days (before 1980), were available almost exclusively in more sublime forms of songs, e.g. literary and stage songs, or sung poetry. The saturation with vulgar expressions, and the freedom of using them and utilising their flexibility in works intended for official publication and public appearances, have become generation trademarks carried forward from the experiences of the new Poland.

\section{Euphemism}

In reference to the above examples, one could become convinced that contemporary songs which utilise modern music forms, and which aspire to describing reality within the textual layer, cannot exist without the use of vulgarisms.

Contrary to such a thesis would be the rich output of Pablopavo ${ }^{32}$, who, while exploring various areas of colloquial speech, manages to use a language almost entirely free of vulgarisms. Expressions such as in "Ośmiu" are rare in his works:

I tylko czasem w knajpie, gdzie

robiłem za silnego

jakiś frajerski, niedopity typ

okazywał się w dodatku niedobity

„Ej, Mistrzu! To jesteś kurwa ty?”

(...)

Liczę ich dokładnie, jak wtedy

w Jaworznie sędzia

kiedy zza rogu wychodzi jeszcze sześć

mord

Może to i lepiej? Sprawa jasna, choć

ciemno

"Ruszaj, skurwysynu! Kozaczyłeś?

To chodź!
And only sometimes at a bar where

I worked as the bouncer

some drunk berk

proved to also be not kicked enough

"Hey, Champ! Is that, fucking, you?"

(...)

I'm counting them carefully, like that time the judge in Jaworzno when from around the corner six more mugs came out Maybe that's even better? The case's clear, though it's dark "Move, you son of a bitch! You think you're a tough guy? Come on then!"

Clearly from the context, they exist as independent speech, as an element of aggressive speech prior to a fight.

The fact of avoiding linguistic rudeness has even become the focus of an amusing play on words in "Telehon". By using an oniric convention for presenting

\footnotetext{
${ }^{32}$ The quotations from Pablopavo's works came from the booklets of respective CDs.
} 
life's smaller or bigger inconveniences requiring mending, the song also includes such a fragment of an idealised world:

Tu internauci i interniści są $\boldsymbol{z a} \ldots$

...bardzo mili, jeśli chcesz trochę chamstwa

musisz naprawdę się wysilić
Here internet users and internists are $f u . .$.

...ndamentally too polite, if you want

some rudeness

you must really try hard

Abandoning a vulgar rhyme and replacing it with a euphemism is also an element of that idealised world. In earlier parts of the lyrics, there appears another metalinguistic reflection stemming from a combination of differently understood aspects of language and personality:

W tym śnie o wiele mniej klnę

Nie zawodzę ludzi, którym mówię

„Kocham Cię"

(...)

Między wyrazami nie powtarzam „e”!
In the dream, I swear much less

I do not let down those to whom I say

'I love you'

(...)

I do not insert 'er' between each word!

Euphemisms in songs, particularly in view of the considerable over-representation of vulgarisms, deserve a separate study. They deserve consideration at least due to the fact that their diversity and linguistic innovation (when compared to previous achievements in songs) should constitute another proof of the progressive nature of the language of the genre - the search for various means of distancing oneself from profane speech.

\section{What can you do with obscenity}

In Co poczać z wulgaryzmami? [What can you do with obscenity?] in the mid-1990s, Halina Wiśniewska diagnosed the expansive nature of vulgarisms in Polish, which were transcending the borderlines set by the level of one's education, their profession, sex, and age. She wrote:

Evidently, the presence of vulgarisms has ceased to be a characteristic differentiating the groups of users of Polish. They have permeated into various social strata from the bottom to the top and sideways; they have expanded onto all age and professional groups unifying Poles verbally, sadly in a negative manner. ${ }^{33}$

\footnotetext{
${ }^{33}$ H. Wiśniewska, op. cit., p. 83. [English version translated from Polish].
} 
The increasing level of obscenity in the language is a fact which can be observed every day in social life, including in the media. It is a result of the complex cultural processes of recent decades, out of which I was able to consider only a few herein. Songs, being a particularly egalitarian area of culture, have clearly recorded those tendencies, probably supporting them by sanctioning pejorative linguistic habits. Today, vulgarisms, over 25 years after liberating the language from the care of censorship, are widely present in songs, which a large number of Poles consider important, good, and wise. That stylistic device helps express, and shapes the manner of expressing, one's emotions, and describe reality, and it is also a manifestation of the generation's fear of loftiness. It has become the focus of various strategies, in some cases it enables one to associate the speaking persona of a song with the performer, and, to the contrary, in others it enables one to remove oneself through the speech of others. The latter operations require trust in the receiver's communication competences, as they must decode meanings resulting from the linguistic attributes of the speaking (singing) persona, identify irony and the distance, a result of the differences between an author's proprietary dominant style, and the persona created by her/him. In such roles, vulgarisms often become an active ingredient of humour. The fact that the noticeable vulgarisation of the language also leads to intentional artistic decisions on euphemising the message is an undoubtedly positive phenomenon.

\section{Bibliography}

Grochowski Maciej, Słownik polskich przekleństw i wulgaryzmów, Wydawnictwo Naukowe PWN, Warszawa 2008.

Jędrzejewski Marek, Młodzież a subkultury. Problematyka edukacyjna, Wydawnictwo Akademickie "Żak", Warszawa 1999.

Język zwierciadłem kultury, czyli nasza codzienna polszczyzna, Halina Zgółkowa (ed.), Wydawnictwo Poznańskie, Poznań 1988

Lewandowski Marcin, Język subkultury punków, Wydawnictwo "Poznańskie Studia Polonistyczne”, Poznań 2007.

Słownictwo współczesnej polszczyzny w okresie przemian, Jan Mazur (ed.), Wydawnictwo Uniwersytetu Marii Curie-Skłodowskiej, Lublin 2000.

Wiśniewska Halina, “Co począć z wulgaryzmami”, Polonistyka 1994, issue 2 (312), pp. 82-86.

Współczesna polszczyzna mówiona w odmianie opracowanej (oficjalnej), Zofia Kurzowa, Władysław Śliwiński (eds.), Universitas, Kraków 1994.

Zgółkowa Halina, "Językowy obraz pokolenia, czyli o języku tekstów rockowych”, Polonistyka 1989, issue 6, pp. 441-449. 
Krzysztof Gajda

Profanity in songs. Seeking the limits of freedom of speech, and the reproduction and sanctioning of contemporary linguistic tendencies

\section{(Summary)}

The article is showing the presence of vulgar expressions in song lyrics. This is a clear testimony to the changes in the customs and language of culture of recent decades. The paradox is that the development of negative phenomena can contribute to events naturally valued positively, such as expanding the sphere of freedom together with the birth of "Solidarity" or the abolition of the censorship institution with the transformation after 1989. Vulgarism today, after more than a quarter of a century since the release of language from the "care" of censorship, is intensively present in songs that many Poles find important. This stylistic device helps to express and shapes the expressed emotions, describe reality, and it is a manifestation of the generational fear of the sublime. The text discusses the songs of authors such as: Andrzej Garczarek, Jacek Kaczmarski, Kazik Staszewski, Krzysztof Grabowski (Grabaż), Marcin Świetlicki, Hubert Dobaczewski (Spięty), Paweł Sołtys (Pablopavo).

Keywords: profanity, vulgarism, song, rock, punk, political transformation, euphemism 